\title{
Soil Management in the Breede River Valley Wine Grape Region, South Africa. 3. Grapevine Performance
}

\author{
J.C. Fourie \\ ARC Infruitec-Nietvoorbij, Private Bag X5026, Stellenbosch, 7599 Republic of South Africa
}

Submitted for publication: August 2010

Accepted for publication: March 2011

Key words: Cover crops, soil management, grapevines, grape yield, shoot growth, grape juice

\begin{abstract}
Eight cover crop treatments were applied for 12 consecutive years on a medium textured soil in a vineyard near Robertson $\left(33^{\circ} 50^{\prime} \mathrm{S}, 1^{\circ} 54^{\prime} \mathrm{E}\right)$. A treatment with full surface straw mulch combined with full surface post-emergence chemical control applied from just before grapevine bud break to harvest (BB) and another with no cover crop combined with $B B$ was also applied. The control consisted of mechanical control in the work row and post-emergence chemical control in the vine row applied from bud break to harvest. In the BB treatments, grapevine shoot growth was significantly higher than in the treatment where a perennial cover crop was established in the work row during both the second (1993/94) and third (1994/95) season after the grapevines were established. The grape yield in all the BB treatments, except the one in which a mixture of Secale cereale L. v. Henog and Vicia faba L. v. Fiord was sown, was significantly higher than that of the control and the treatment in which a perennial cover crop was sown in the work row during the 1995/96 season. During the 2001/02 season, the grape yield of the BB treatment with a full surface straw mulch was significantly higher than that of all the other treatments. The different soil management practices had a significant effect on the $N$ status of the juice, but did not affect wine quality.
\end{abstract}

\section{INTRODUCTION}

Maintenance and improvement of soil quality is critical if agricultural productivity and environmental quality is to be sustained for future generations (Reeves, 1997). Consumers of agricultural products demand that the use of chemicals and the negative impact of agricultural practices on the environment must be restricted. An increasing number of weed species are developing resistance towards herbicides (Anonymous, 1997; Henkes, 1997). At least 286 weed biotypes are resistant to one or more of the herbicide families documented (Westra et al., 2008). Uncontrolled weeds may reduce crop yield by as much as $80 \%$ (Cousens \& Mortimer, 1995), making effective and sustainable weed control essential. Conventional control methods being used in the vineyards of South Africa consist of weeds being allowed to grow during winter and applying either chemical weed control or mechanical control in the work row combined with chemical control in the vine row from bud break to harvest. Cover crops can be employed as a non-specific biological method of pre-emergence weed control in both the temperate and semi-arid grape producing areas of South Africa (Van Huyssteen et al., 1984; Fourie et al., 2001; Fourie, 2005; Fourie et al., 2005; Fourie et al., 2006a; Fourie et al., 2006c). The use of cover crops has many advantages, inter alia the reduction of water runoff and erosion (Khan et al., 1986; Roth et al., 1988; Louw \& Bennie, 1992), restriction of evaporation from the soil surface (Van Huyssteen et al., 1984; Myburgh, 1998), soil water conservation (Buckerfield \& Webster, 1996), as well as the reduction of temperature fluctuations in the soil
(Van Huyssteen et al., 1984; Fourie \& Freitag, 2010).

Grape yield and pruning mass were significantly affected by soil cultivation practices applied to both non-irrigated (Van Huyssteen \& Weber, 1980) and irrigated (Fourie et al., 2006b) medium textured soils in the Mediterranean Coastal wine grape region, as well as to an irrigated sandy soil in the semi-arid Olifants River Valley (Fourie et al., 2007). Fourie et al. (2006b) indicated that $\mathrm{N}$-fixing species should not be used continuously as cover crops over the long term on medium textured soils, as it may eventually cause vigorous grapevine growth and a decline in the production of quality grapes. This, however, did not occur on the less fertile sandy soils of the semi-arid Olifants River Valley, but instead allowed for a significant reduction in the annual application of inorganic $\mathrm{N}$ after bud break (Fourie et al., 2007). Using $\mathrm{N}$ fixing cover crop species, such as Vicia dasycarpa Ten. (grazing vetch), Ornithopus sativus L. v. Emena (pink Seradella) and two Medicago truncatula Gaertn. (Burr medic) varieties, in combination with full surface post-emergence chemical control from just before grapevine bud break to harvest on these sandy soils, resulted in significantly higher grape yields than in vineyards where clean or mechanical soil cultivation was applied from bud break. The use of a permanent growing cover (weeds or cover crop) in the work row has been shown to reduce grapevine vigour (Van Huyssteen \& Weber, 1980; Soyer et al., 1984; Lombard et al., 1988; Pool et al., 1990; Sicher et al., 1995; Pinamonti et al., 1996; Ingels et al., 2005) and yield (Van Huyssteen \& Weber, 1980; Soyer et al., 1984; Lombard et al., 1988; Sicher et al.,

*Corresponding author: E-mail address: FourieJ@arc.agric.za

Acknowledgements: The author thanks the ARC and Winetech for financial support, as well as the staff of the Soil \& Water Science Programme of ARC InfruitecNietvoorbij for technical support 
1995; Pinamonti et al., 1996) compared to grapevines grown under other soil cultivation practices. Pool et al. (1990) and Ingels et al. (2005), however, reported no difference, whereas Anonymous (1984) reported higher yields for grapevines with a permanent cover crop in comparison with grapevines in which other soil cultivation practices were applied. Grape yield under winter growing cover crops controlled chemically before bud break was significantly higher than that of grapevines in which chemical clean cultivation (Buckerfield \& Webster, 1996; Fourie et al., 2006b; Fourie et al., 2007) and mechanical clean cultivation (Fourie et al., 2006b; Fourie et al., 2007) were applied. Buckerfield \& Webster (1996) observed that the yield of grapevines with full surface straw mulch was significantly higher than that of grapevines in which clean cultivation was applied.

A permanent grass cover crop significantly decreased the $\mathrm{N}$ concentration in grapevine leaves compared to that of vines in which full surface chemical control was applied (Soyer et al., 1984; Lombard et al., 1988; Tan \& Crabtree, 1990; Sicher et al., 1995; Pinamonti et al., 1996). A higher grapevine petiole $\mathrm{N}$ was observed where a cover crop was disked in during early spring in comparison with a vineyard in which weeds were disked in (Ingels et al., 2005; Fourie et al., 2007) or in comparison with a vineyard in which the cover crops were slashed (Ingels et al., 2005). Nitrogen fixing cover crops, such as the Vicia and Medicago species, resulted in significantly higher grapevine petiole $\mathrm{N}$ in comparison with vineyards in which no cover crops were sown and either mechanical or chemical control was applied in the work row (Fourie et al. 2006b; Fourie et al., 2007).

According to Lombard et al. (1988) and Ingels et al. (2005), soil cultivation did not affect the soluble solids content and acidity of grape juice at harvest. Van Huyssteen (1990), Fourie et al. (2006b) and Fourie et al. (2007), however, reported significant differences in total titratable acids (TTA) of grape juice between soil cultivation treatments. The differences in TTA were attributed to differences in crop size (Fourie et al., 2006b) and vegetative growth (Conradie, 2001; Fourie et al., 2006b). A permanent green cover in the work row competed with the grapevines for nutrients during the growing season, which resulted in the must being either low in ammonium-N (Dupuch, 1997) or N deficient (Van Huyssteen, 1990). This increased the time necessary to ferment all the sugar in the must (Dupuch, 1997), or caused stuck fermentation to occur (Van Huyssteen, 1990). According to Maigre (1997), a permanent grass cover in the work row had a negative effect on wine quality during years when the competition between the grass and the grapevines was high. Wine quality was, however, not affected negatively where annual cover crops were sown and full surface post-emergence chemical weed control was applied when the berries reached pea size (Fourie et al., 2006b; Fourie et al, 2007).

The reviewed literature indicates that soil management practices impact significantly on grapevine performance. Cover crop growth and $\mathrm{N}$ contributed by them depend on species, length of growing season, climate and soil conditions (Shennan, 1992). The effect of annual cover crops controlled chemically during different stages of the grapevine growing season on the performance of both young and fully grown Chardonnay/99 Richter vines established on a medium textured soil in the temperate Coastal wine grape region (Fourie et al., 2006b) was determined. A similar study was done on a Sauvignon blanc/Ramsey vines established on a sandy soil in the semiarid Olifants River Valley (Fourie et al., 2007). This study was conducted to determine the effect of different soil cultivation and cover crop management practices on the performance of Chardonnay/99 Richter vines established on a medium textured soil in the semi-arid Breede River Valley wine grape region. The aim was to supply the wine grape industry with guidelines for sustainable cover crop management over the long term in vineyards established on these soils in the Breede River Valley wine grape region.

\section{MATERIALS AND METHODS \\ Experiment vineyard and layout}

The experimental procedures and layout were previously described in detail by Fourie (2010). The trial was carried out in a Chardonnay/99 Richter vineyard trained on a seven strand, double lengthened Perold trellis system (Booysen et al., 1992) and established on a medium textured soil at the ARC Infruitec-Nietvoorbij research farm near Robertson during November 1992. Robertson $\left(33^{\circ} 50^{\prime} \mathrm{S}, 1^{\circ} 54^{\prime} \mathrm{E}\right)$ is situated in the Breede River Valley region of the Western Cape. Mean annual rainfall is $278 \mathrm{~mm}$, of which approximately $178 \mathrm{~mm}$ falls from March to August. The grapevines were spaced 1.5 $\mathrm{m}$ in the row and $2.75 \mathrm{~m}$ between rows. The cover crops were sown annually during mid April (seeding dates varying between 4 and 15 April) at seeding densities suggested by Fourie et al. (2001), with the exception of 1993 when infra-structural work delayed sowing until 24 May. Seedbed preparation was done with a disc harrow approximately six weeks before the seeding date. After sowing by hand, the seeds were covered using a disc harrow. The vineyard was irrigated by means of 25.7 $\mathrm{L} / \mathrm{h}$ micro-sprinklers with a $360^{\circ}$ wetting pattern. The microsprinklers were installed on the irrigation line in an upright position at $1.5 \mathrm{~m}$ intervals. Irrigation was scheduled according to the guidelines supplied by Fourie et al. (2001) from the day the cover crops were planted until the end of August. During summer the soil water content was determined weekly with a neutron moisture probe (CPN, series number H340502024). The neutron moisture probe was calibrated against gravimetric soil water content. Plant available water (PAW) was defined as the water retained between field water capacity and $-0.1 \mathrm{MPa}$, and the grapevines were irrigated to field water capacity when approximately $60 \%$ PAW was depleted (P.A. Myburgh, personal communication, 1993). The grapevines received $14 \mathrm{~kg} / \mathrm{ha}$ of $\mathrm{N}$ during seedbed preparation (first week of March), as well as 14 $\mathrm{kg} / \mathrm{ha}$ of $\mathrm{N}$ at the two to four leaf development phases of the grass cover crops. In the case of the $\mathrm{N}$-fixing broadleaf cover crops, the $\mathrm{N}$ was applied to the grapevine row only, while in the other treatments it was broadcast. The vines were spur-pruned according to vigour and suckered a few weeks after bud break. Shoot positioning was done and the vines tipped and topped as soon as the canes grew more than $100 \mathrm{~mm}$ past the highest line of the trellis system (approximately $1.1 \mathrm{~m}$ above the cordon of the vine). Post-emergence chemical weed control was achieved by spraying glyphosate at a rate of $1.44 \mathrm{~kg}$ active ingredient $/ \mathrm{ha}$ using a tractor sprayer.

Eleven treatments were applied as shown in Table 1. Six of these treatments consisted of full surface post-emergence 
chemical weed control from just before grapevine bud break (end of August) to harvest (BB) being applied to winter growing weeds (T2), Triticale v. Usgen 18 (triticale)(T4), grazing vetch (T6), a mixture of Secale cereale L. v. Henog (rye) and Vicia faba L v. Fiord (faba bean) (T8), an annual rotation of triticale and vetch (T9), as well as a biennial rotation of triticale and vetch (T10). Two treatments consisted of triticale (T5) and vetch (T7) being sown annually as cover crops, respectively, with post-emergence chemical weed control being applied to a $1 \mathrm{~m}$ wide strip in the vine row just before grapevine bud break (end of August), followed by full surface post-emergence chemical control from the stage when the grapevine berries reached pea size (end of November) to just before harvest (end of January) (AB). A full surface straw mulch, packed out at a density of approximately eight tons per hectare during grapevine bud break, combined with BB was also included in the trial (T3). Another treatment consisted of Festuca arundinacae L. v. Cochise (dwarf Fescue) being slashed in the work row throughout the season, with post-emergence chemical weed control being applied to a $1 \mathrm{~m}$ wide strip in the vine row from just before grapevine bud break to harvest (T11). These treatments were compared to a control, in which no cover crop was sown and post-emergence chemical weed control was applied to a $1 \mathrm{~m}$ wide strip in the vine row from just before grapevine bud break to harvest (T1).

\section{Measurements \\ Shoot mass and grape yield}

Shoot mass and grape yield were measured for 12 seasons (1993/94 to 2004/05) and 11 seasons (1994/95 to 2004/05), respectively. All treatments were harvested on the same date in a specific year.

\section{Bunches per shoot}

The number of bunches per shoot were determined at full bloom for five seasons (1998/99 to 2002/03).

\section{Berry weight and volume}

Berry weight and volume were determined from 1998/99 to $2002 / 03$. One hundred berries were picked randomly from 10 bunches per treatment plot during harvest. The berries were weighed and their volume determined volumetrically.

\section{Leaf petiole analysis}

Petiole analyses were carried out over nine seasons (1994/95 to 2002/03). Leaf petioles were collected at full bloom from locations directly opposite clusters. Leaves and petioles were separated immediately after sampling. Petiole samples were extracted with $1.0 \mathrm{M} \mathrm{KCl}$ and analysed colorimetrically for $\mathrm{NO}_{3}-\mathrm{N}$ (The Non-affiliated Soil Analysis Work Committee, 1990).

\begin{abstract}
Juice analysis
Grapes were harvested when the sugar concentration averaged $22^{\circ} \mathrm{B}$. A representative sample (approximately one bunch per experimental vine) from each plot was crushed in a hydraulic press. Free run juice was analysed for sugar content (temperature compensated Abbé refractometer), total titratable acid $(50 \mathrm{~mL}$ juice titrated with $0.333 \mathrm{M} \mathrm{NaOH}$ to $\mathrm{pH} 7.0$ and expressed as $\mathrm{g}$ tartaric acid/L) and $\mathrm{pH}$ (654 Metrohm $\mathrm{pH}$ meter). Total juice $\mathrm{N}$ was determined using an automated colorimetric method (The Non-affiliated Soil Analysis Work Committee, 1990), following digestion with selenous acid/sulphuric acid. All these measurements were done for 11 seasons (1994/95 to 2004/05). Total P, K, Ca and Mg concentrations in the juice were determined for six years (1994/95 to 1999/2000) by
\end{abstract}

TABLE 1

Treatments applied from April 1993 to March 2005.

\section{Treatment}

No cover crop, post-emergence chemical control of a $1 \mathrm{~m}$ wide strip in the vine row from just before grapevine bud break (end of August) to just before harvest (end of January) (VR) and mechanical cultivation in the work row during the same period.

No cover crop, full surface post-emergence chemical control from the end of August to the end of January (BB)

Treatment code

Eight t/ha straw mulch packed out full surface just after grapevine bud break (third week of September), BB

Triticale v.Usgen 18 (triticale) sown annually (100 kg/ha), BB.

Triticale sown annually $(100 \mathrm{~kg} / \mathrm{ha})$. Post-emergence chemical control of a $1 \mathrm{~m}$ wide strip in the vine row end of August and full surface post-emergence chemical control from when the berries reached pea size (end of November) to the end of January (AB)

Vicia dasycarpa Ten. (vetch) sown annually (50 kg/ha), BB

Vetch sown annually (50 kg/ha), AB

A Secale cereale L. v. Henog (rye) and Vicia faba L. v. Fiord (Faba bean) mixture sown annually (50 kg/ha and 60 $\mathrm{kg} / \mathrm{ha}$, respectively), BB.

Triticale (100 kg/ha) and vetch (50 kg/ha) rotated annually, BB

Festuca arundinacae L. v. Cochise (dwarf Fescue) established during 1993 (15 kg/ha) and 1998 (15 kg/ha). VR and slashing in the work row throughout the season 
atomic absorption spectrophotometry, following digestion with nitric acid/perchloric acid.

\section{Experimental wines}

Experimental wines were prepared from the grapes of eight selected treatments, as described by Fourie et al. (2006b). The wines were stored at $14^{\circ} \mathrm{C}$ for three months before evaluation. Sensory evaluation was carried out by an experienced panel of 14 members on a nine point scorecard (Tromp \& Conradie, 1979). The wines were presented in coded form and evaluated for overall wine quality, as well as for aroma and taste. This was repeated for six consecutive seasons (1996/97 to 2001/2002)

\section{Statistical procedures}

The experiment was a complete randomized design with 11 treatments replicated four times. The treatments were repeated for 12 consecutive seasons (years). The size of each replication (plot) was $165 \mathrm{~m}^{2}$. Ten experimental grapevines per plot were used for measurements. Individual plots were separated by two border grapevine rows and five border grapevines within rows. Analyses of variance were performed for each season separately, using SAS (SAS, 1990). Student's $t$ least significant difference (LSD) was calculated at the $5 \%$ significance level to facilitate comparison between treatment means. The ShapiroWilk test was performed to test for non-normality (Shapiro \& Wilk, 1965).

\section{RESULTS AND DISCUSSION \\ Grape yield and shoot mass}

The trends between treatments differed from year to year. Training of the permanent structure of the grapevines was completed during the 1993/94 growing season (second growing season, first season of the experiment). Differences in the vegetative growth of the grapevines became apparent at the end of that season (Table 2). The shoot masses of the twoyear-old grapevines (1993/94 season) in the treatments in which full surface post-emergence chemical weed control was applied from the end of August to just before harvest (T2, T3, T4, T6, T8, T9 and T10) were significantly higher than that of T11. This trend also manifested in the 1994/95 season. The shoot mass of the two-year-old grapevines in T10 was also significantly higher than that of $\mathrm{T} 1, \mathrm{~T} 5$ and $\mathrm{T} 7$. With the exception of T5, this trend continued into the 1994/95 season. These results indicate that, in young vineyards established on medium textured soils in the semi-arid Breede River Valley, cover crops should be sown annually and controlled chemically before bud break, as this practice enhances the development of the permanent structure of grapevines. This observation corresponds with those of Fourie et al. (2006b) and Fourie et al. (2007). The first harvest from the grapevines in T5 and T10 was significantly higher than that of T11 (Table 2). It seems that the short period in which the triticale completed its life cycle, as well as the excellent weed control achieved in T5 during the growing season of the grapevines (Fourie, 2010), resulted in this treatment producing a harvest similar in size to that of

TABLE 2

Effect of different soil cultivation practices and cover crops on the shoot mass (SM) and grape yield (GY) of young Chardonnay/99 Richter vines, established on a medium textured soil near Robertson, as measured from the first (1993/94) to the third (1995/96) season of the experiment.

\begin{tabular}{|c|c|c|c|c|c|}
\hline \multirow[b]{2}{*}{ Treatment } & \multirow{2}{*}{$\frac{1993 / 94^{1}}{\mathrm{SM}}$} & \multicolumn{2}{|c|}{$1994 / 95$} & \multicolumn{2}{|c|}{$1995 / 96$} \\
\hline & & $\begin{array}{c}\mathrm{SM} \\
\text { (t/ha) }\end{array}$ & $\begin{array}{c}\text { GY } \\
\text { (t/ha) }\end{array}$ & $\begin{array}{c}\text { SM } \\
\text { (t/ha) }\end{array}$ & $\begin{array}{c}\text { GY } \\
(\mathrm{t} / \mathrm{ha})\end{array}$ \\
\hline T1. No cover crop, $\mathrm{MC}^{2}$ (Control) & 0.29 & 0.93 & 2.32 & 1.31 & 8.24 \\
\hline T2. No cover crop, $\mathrm{BB}^{3}$ & 0.39 & 1.09 & 2.62 & 1.74 & 11.02 \\
\hline T3. Full surface straw mulch, BB & 0.46 & 1.09 & 3.53 & 1.57 & 11.40 \\
\hline T4. Triticale v. Usgen 18 (triticale), BB & 0.41 & 1.12 & 2.87 & 2.11 & 10.67 \\
\hline T5. Triticale, $\mathrm{AB}^{4}$ & 0.27 & 1.17 & 3.65 & 2.03 & 10.55 \\
\hline T6. Vicia dasycarpa Ten. (vetch), BB & 0.34 & 1.26 & 2.99 & 1.90 & 10.77 \\
\hline T7. Vetch, AB & 0.19 & 0.81 & 2.18 & 1.38 & 8.84 \\
\hline T8. Secale cereale L. v. Henog (rye)/Vicia faba L. v. Fiord (faba bean) mixture, BB & 0.37 & 1.19 & 3.05 & 2.02 & 10.04 \\
\hline T9. Triticale/vetch rotated annually, BB & $0.38^{\mathrm{t}}$ & 1.25 & 2.57 & $2.04^{\mathrm{t}}$ & $10.36^{\mathrm{t}}$ \\
\hline T10. Triticale/vetch rotated biennially, BB & $0.52^{\mathrm{t}}$ & $1.48^{\mathrm{t}}$ & $3.67^{\mathrm{t}}$ & 2.36 & 12.16 \\
\hline T11. Festuca arundinacae L. v. Cochise (dwarf Fescue), SL 5 & 0.13 & 0.57 & 1.99 & 1.43 & 7.51 \\
\hline $\operatorname{LSD}(p \leq 0.05)$ & 0.20 & 0.22 & 1.64 & 0.88 & 2.09 \\
\hline
\end{tabular}

${ }^{1}$ Cover crops established 24 May instead of mid-April. ${ }^{2} \mathrm{MC}=$ post-emergence chemical control in vine row and mechanical control in working row from the end of August. ${ }^{3} \mathrm{BB}=$ full surface post-emergence chemical control from the end of August. ${ }^{4} \mathrm{AB}=$ postemergence chemical control in vine row at the end of August, full surface post-emergence chemical control from when the grape berries reached pea size (end of November). ${ }^{5}$ Chemical control in vine row from end of August, work row slashed throughout the season. ${ }^{\mathrm{t}}$ Year in which triticale was sown. 
T10. The shoot mass and harvest of T11 being the lowest of all the treatments (Table 2) support the observations of Van Huyssteen \& Weber (1980), Soyer et al. (1984), Lombard et al. (1988), Sicher et al. (1995), and Pinamonti et al. (1996).

During the 1995/96 season (fourth growing season, third of the experiment), the differences in shoot mass between the BB treatments (T2, T3, T4, T6, T8, T9 and T10) and T11 were less than those observed in the 1993/94 and 1994/95 seasons (Table 2). The shoot mass in T10, however, remained significantly higher than that of $\mathrm{T} 1, \mathrm{~T} 7$ and $\mathrm{T} 11$. In contrast to shoot mass, the differences in grape yield between treatments became more pronounced. The grape yield in the BB treatments was, with the exception of T8, significantly higher than that of T1 and T11 during the 1995/96 season. The grape yield in T5 was also significantly higher than that of T1 and T11. This difference in yield was attributed to triticale completing its life cycle shortly after grapevine bud break, as well as to the excellent weed control achieved in T5 during the 1995/96 grapevine growing season (Fourie, 2010). These results indicate that full surface post-emergence chemical control should be applied from the end of August to just before harvest during the first four seasons after a vineyard was established on medium textured soils in the Breede River Valley.

The shoot mass did not differ between treatments during the $1996 / 97$ to $1998 / 99$ seasons and the 2001/02 season (Table 3). The shoot mass of T3 was significantly higher than that of the other treatments during 1999/2000 season. This trend continued for the duration of the trial, although the differences were not significant. The grape yield in this treatment was also the highest from the 1996/97 season onwards, with the exception of the 2000/01 season. During the 1996/97 season (fifth growing season, fourth of the experiment) the grape yield in T2, T3, and all the treatments in which a cover crop was sown annually (T4 to T10) was significantly higher than that of T1 and T11. As far as T1 is concerned, this trend continued during the 1997/98 season, except for T7. The grape yield in T3 and T10 was also significantly higher than that of T2 during the $1996 / 97$ season. Grape yields in all the treatments continued to increase up to the 1997/98 season (sixth growing season, fifth of the experiment), with the exception of T7, T9 and T10 which reached full production one season earlier. In T7, grape yields showed a decrease of $8 \%$ between the 1996/97 and 1997/98 seasons. The trends in grape yield observed during the 1998/99 season were similar to those that occurred during the 1997/98 season. During the 1998/99 season (seventh growing season, sixth season of the experiment), however, the grape yield in T11 was, for the first time, significantly higher than that of T1. The continuing decline in grape yield observed in T7 (Table 3) was attributed to the poor performance of the cover crop (grazing vetch) during the 1997/98 and 1998/99 seasons, which resulted in poor control of the summer growing weeds (Fourie, 2010), thereby increasing the competition between the weeds and the grapevines for water and nutrition. This competition resulted in the grape yield in $\mathrm{T} 7$ being significantly lower than that of

\section{TABLE 3}

Effect of different soil cultivation practices and cover crops on the shoot mass (SM) and grape yield (GY) of full bearing Chardonnay/99 Richter vines, established on a medium textured soil near Robertson, as measured from the fourth (1996/97) to the ninth (2001/02) season of the experiment.

\begin{tabular}{|c|c|c|c|c|c|c|c|c|c|c|c|c|}
\hline \multirow[b]{2}{*}{ Treatment } & \multicolumn{2}{|c|}{$1996 / 97$} & \multicolumn{2}{|c|}{$1997 / 98$} & \multicolumn{2}{|c|}{ 1998/99 } & \multicolumn{2}{|c|}{$1999 / 2000$} & \multicolumn{2}{|c|}{$2000 / 01$} & \multicolumn{2}{|c|}{$2001 / 02$} \\
\hline & $\begin{array}{c}\mathrm{SM} \\
(\mathrm{t} / \mathrm{ha})\end{array}$ & $\begin{array}{c}\text { GY } \\
(\mathrm{t} / \mathrm{ha})\end{array}$ & $\begin{array}{c}\mathrm{SM} \\
(\mathrm{t} / \mathrm{ha})\end{array}$ & $\begin{array}{c}\mathrm{GY} \\
(\mathrm{t} / \mathrm{ha})\end{array}$ & $\begin{array}{c}\mathrm{SM} \\
(\mathrm{t} / \mathrm{ha})\end{array}$ & $\begin{array}{c}\mathrm{GY} \\
(\mathrm{t} / \mathrm{ha})\end{array}$ & $\begin{array}{c}\text { SM } \\
(\mathrm{t} / \mathrm{ha})\end{array}$ & $\begin{array}{c}\text { GY } \\
(\mathrm{t} / \mathrm{ha})\end{array}$ & $\begin{array}{c}\mathrm{SM} \\
(\mathrm{t} / \mathrm{ha})\end{array}$ & $\begin{array}{c}\text { GY } \\
(\mathrm{t} / \mathrm{ha})\end{array}$ & $\begin{array}{c}\text { SM } \\
(\mathrm{t} / \mathrm{ha})\end{array}$ & $\begin{array}{c}\text { GY } \\
(\mathrm{t} / \mathrm{ha})\end{array}$ \\
\hline T1. No cover crop, $\mathrm{MC}^{1}$ (Control) & 2.70 & 12.10 & 2.41 & 14.16 & 2.30 & 12.40 & 2.55 & 14.90 & 2.22 & 10.79 & 2.83 & 14.00 \\
\hline T2. No cover crop, $\mathrm{BB}^{2}$ & 3.22 & 14.50 & 2.38 & 15.37 & 2.61 & 15.30 & 2.14 & 15.00 & 2.21 & 13.50 & 2.71 & 16.65 \\
\hline T3. Full surface straw mulch, BB & 3.37 & 17.53 & 2.56 & 19.72 & 2.57 & 19.00 & 3.02 & 17.93 & 2.48 & 13.98 & 3.00 & 19.33 \\
\hline T4. Triticale v. Usgen 18 (triticale), BB & 3.25 & 15.69 & 2.47 & 16.18 & 2.51 & 16.84 & 2.41 & 16.17 & 2.11 & 13.75 & 2.93 & 16.95 \\
\hline T5. Triticale, $\mathrm{AB}^{3}$ & 3.30 & 16.12 & 2.40 & 17.70 & 2.45 & 16.70 & 2.14 & 15.00 & 1.85 & 12.58 & 2.81 & 14.62 \\
\hline T6. Vicia dasycarpa Ten. (vetch), BB & 3.15 & 15.77 & 2.58 & 16.17 & 2.61 & 15.77 & 2.53 & 16.20 & 2.33 & 14.20 & 2.86 & 16.37 \\
\hline T7. Vetch, AB & 2.69 & 16.03 & 2.35 & 14.78 & 2.43 & 13.80 & 2.23 & 14.40 & 1.93 & 11.67 & 2.89 & 14.87 \\
\hline $\begin{array}{l}\text { T8. Secale cereale L. v. Henog (rye)/Vicia } \\
\text { faba L. v. Fiord (faba bean) mixture, BB }\end{array}$ & 3.18 & 15.55 & 2.51 & 16.53 & 2.34 & 16.60 & 2.37 & 16.30 & 2.09 & 13.74 & 2.91 & 16.44 \\
\hline T9. Triticale/vetch rotated annually, BB & 2.71 & 16.71 & $2.40^{\mathrm{t}}$ & $16.61^{\mathrm{t}}$ & 2.30 & 16.13 & $2.21^{\mathrm{t}}$ & $15.55^{\mathrm{t}}$ & 2.09 & 14.11 & $2.58^{\mathrm{t}}$ & $16.43^{\mathrm{t}}$ \\
\hline T10. Triticale/vetch rotated biennially, BB & 3.35 & 17.39 & $2.52^{\mathrm{t}}$ & $17.24^{\mathrm{t}}$ & $2.61^{\mathrm{t}}$ & $17.40^{\mathrm{t}}$ & 2.60 & 16.20 & 2.19 & 14.54 & $2.96^{t}$ & $16.49^{\mathrm{t}}$ \\
\hline $\begin{array}{l}\text { T11. Festuca arundinacae L. v. Cochise } \\
\text { (dwarf Fescue), SL }{ }^{4}\end{array}$ & 2.56 & 12.41 & 2.23 & 15.83 & 2.27 & 15.40 & 2.37 & 15.64 & 2.06 & 13.28 & 2.95 & 16.55 \\
\hline $\operatorname{LSD}(\mathrm{p} \leq 0.05)$ & NS & 2.69 & NS & 2.01 & NS & 2.30 & 0.41 & 2.60 & 0.27 & 2.00 & NS & 2.30 \\
\hline
\end{tabular}

${ }^{1} \mathrm{MC}=$ post-emergence chemical control in vine row and mechanical control in working row from the end of August. ${ }^{2} \mathrm{BB}=$ full surface post-emergence chemical control from the end of August. ${ }^{3} \mathrm{AB}=$ post-emergence chemical control in vine row at the end of August, full surface post-emergence chemical control from when the grape berries reached pea size (end of November). ${ }^{4} \mathrm{Chemical}$ control in vine row from end of August, work row slashed throughout the season. ${ }^{\text {t}}$ Year in which triticale was sown. 
the treatments in which a cover crop was sown annually (except T6) during the 1998/99 season (Table 3). The differences in grape yields between treatments were observed to be less prominent during the 1999/2000 season, with only that of T3 being significantly higher than those of T1, T2, T5 and T7. Similar to the trends observed during the 1995/96 and 1998/99 seasons, the grape yield in all the BB treatments (T2, T3, T4, T6, T8, T9 and T10) were significantly higher than that of T1 in the 2000/01 and 2001/02 seasons. During the 2001/02 season, the grape yield in T3 was significantly higher than that of all the other treatments, which corresponded with the trend observed during the 1997/98 season. The grape yield in T6 was significantly higher than that of T7 during the 2000/01 season, with the same trend, though not significant, being observed for the 2001/02 season. The grape yield in T4 tended to be higher than that of T5 during the 2000/01 season, with the difference becoming significant during the 2001/02 season. This supports the results of Fourie et al. (2006b) and Fourie et al. (2007). The trends observed during the 2002/03 to 2004/05 seasons corresponded with those observed during the 2000/01 season (data not shown).

\section{Bunches per shoot}

The number of bunches per shoot did not differ significantly during the 1998/99, 1999/2000 and 2001/02 seasons (data not shown). The number of bunches per shoot in T3 was, with the exception of T2, significantly lower that of the other treatments during the 2000/01 season (Table 4). This difference was attributed to shoot mass in T3 being significantly higher than that of all the other treatments during the 1999/2000 season
(Table 3), which might have caused the buds to be less fertile in the 2000/01 season. Although vegetative growth in T3 during the 2001/02 season was similar to that of the 1999/2000 season (Table 3), it did not have a negative effect on bud fertility (Table 4). This indicated that the effect that this level of shoot growth had on bud fertility was marginal and could be overshadowed by other seasonal effects.

\section{Berry mass and volume}

The berry mass and volume differed significantly between treatments during the 1999/2000 and 2000/01 seasons (Table 5). These differences did not, however, correlate with grape yield size, as illustrated by the berry mass and volume in the treatments producing the highest yield, namely T3 (1999/2000 season) and T10 (2000/01 season) not differing significantly from those of the treatments producing the lowest yields, namely T7 (1999/2000 season) and T1 (2000/01 season), respectively (Tables $3 \&$ 5). During these two seasons T1 and T11 produced berries with the highest mass and greatest volume. The reason for this trend is not clear.

\section{Leaf petiole analysis}

The trends between treatments differed from year to year. The $\mathrm{NO}_{3}-\mathrm{N}$ concentration of the petioles for years selected to illustrate the impact that the soil cultivation practices had on grapevine nutrient status early in the grapevine growing season over time, are presented in Table 6 . The $\mathrm{NO}_{3}-\mathrm{N}$ concentration in the petioles of the grapevines during the 1995/96 season indicated that, according to the norms of Conradie (1994), the grapevines in $\mathrm{T} 1$ and $\mathrm{T} 11$ experienced serious $\mathrm{N}$ deficiencies

TABLE 4

Effect of different soil cultivation practices and cover crops on the bud fertility (expressed as bunches per shoot) of full bearing Chardonnay/99 Richter vines, established on a medium textured soil near Robertson, as measured during the eighth (2000/01) and tenth $(2002 / 03)$ season of the experiment.

\begin{tabular}{|c|c|c|}
\hline \multirow{2}{*}{ Treatment } & \multicolumn{2}{|c|}{ Number of bunches per shoot } \\
\hline & $2000 / 01$ & $2002 / 03$ \\
\hline T1. No cover crop, $\mathrm{MC}^{1}$ (Control) & 2.08 & 1.72 \\
\hline T2. No cover crop, $\mathrm{BB}^{2}$ & 1.90 & 1.82 \\
\hline T3. Full surface straw mulch, BB & 1.61 & 1.95 \\
\hline T4. Triticale v. Usgen 18 (triticale), BB & 2.06 & 1.88 \\
\hline T5. Triticale, $\mathrm{AB}^{3}$ & 2.32 & 1.98 \\
\hline T6. Vicia dasycarpa Ten. (vetch), BB & 2.15 & 2.15 \\
\hline T7. Vetch, AB & 2.12 & 2.04 \\
\hline T8. Secale cereale L. v. Henog (rye)/Vicia faba L. v. Fiord (faba bean) mixture, BB & 2.49 & 1.76 \\
\hline T9. Triticale/vetch rotated annually, BB & 2.21 & $1.88^{\mathrm{t}}$ \\
\hline T10. Triticale/vetch rotated biennially, BB & 2.31 & 1.98 \\
\hline T11. Festuca arundinacae L. v. Cochise (dwarf Fescue), SL ${ }^{4}$ & 2.07 & 1.79 \\
\hline $\operatorname{LSD}(\mathrm{p} \leq 0.05)$ & 0.39 & 0.26 \\
\hline
\end{tabular}

${ }^{1} \mathrm{MC}=$ post-emergence chemical control in vine row and mechanical control in working row from the end of August. ${ }^{2} \mathrm{BB}=$ full surface post-emergence chemical control from the end of August. ${ }^{3} \mathrm{AB}=$ post-emergence chemical control in vine row at the end of August, full surface post-emergence chemical control from when the grape berries reached pea size (end of November). ${ }^{4} \mathrm{Chemical}$ control in vine row from end of August, work row slashed throughout the season. 'Year in which triticale was sown. 
TABLE 5

Effect of different soil cultivation practices and cover crops on the berry mass and berry volume of full bearing Chardonnay/99 Richter vines, established on a medium textured soil near Robertson, as measured during the seventh (1999/2000) and eighth (2000/01) season of the experiment.

\begin{tabular}{|c|c|c|c|c|}
\hline \multirow[b]{2}{*}{ Treatment } & \multicolumn{2}{|c|}{$1999 / 2000$} & \multicolumn{2}{|c|}{$2000 / 2001$} \\
\hline & $\begin{array}{l}\text { Berry mass } \\
\quad(\mathrm{g})\end{array}$ & $\begin{array}{c}\text { Berry } \\
\text { volume } \\
\left(\mathrm{cm}^{3}\right)\end{array}$ & $\begin{array}{l}\text { Berry mass } \\
\quad(\mathrm{g})\end{array}$ & $\begin{array}{c}\text { Berry } \\
\text { volume } \\
\left(\mathrm{cm}^{3}\right)\end{array}$ \\
\hline T1. No cover crop, $\mathrm{MC}^{1}$ (Control) & 1.58 & 1.48 & 1.51 & 1.38 \\
\hline T2. No cover crop, $\mathrm{BB}^{2}$ & 1.52 & 1.41 & 1.35 & 1.24 \\
\hline T3. Full surface straw mulch, BB & 1.55 & 1.41 & 1.39 & 1.28 \\
\hline T4. Triticale v. Usgen 18 (triticale), BB & 1.42 & 1.30 & 1.39 & 1.28 \\
\hline T5. Triticale, $\mathrm{AB}^{3}$ & 1.44 & 1.30 & 1.38 & 1.26 \\
\hline T6. Vicia dasycarpa Ten. (vetch), BB & 1.48 & 1.32 & 1.41 & 1.29 \\
\hline T7. Vetch, AB & 1.37 & 1.24 & 1.36 & 1.24 \\
\hline $\begin{array}{l}\text { T8. Secale cereale L. v. Henog (rye)/Vicia faba L. v. Fiord } \\
\text { (faba bean) mixture, BB }\end{array}$ & 1.39 & 1.26 & 1.35 & 1.25 \\
\hline T9. Triticale/vetch rotated annually, BB & $1.45^{\mathrm{t}}$ & $1.32^{\mathrm{t}}$ & 1.36 & 1.22 \\
\hline T10. Triticale/vetch rotated biennially, BB & 1.39 & 1.27 & 1.34 & 1.23 \\
\hline T11. Festuca arundinacae L. v. Cochise (dwarf Fescue), $\mathrm{SL}^{4}$ & 1.63 & 1.46 & 1.51 & 1.39 \\
\hline $\operatorname{LSD}(\mathrm{p} \leq 0.05)$ & 0.14 & 0.14 & 0.12 & 0.12 \\
\hline
\end{tabular}

${ }^{1} \mathrm{MC}=$ post-emergence chemical control in vine row and mechanical control in working row from the end of $\mathrm{August} .{ }^{2} \mathrm{BB}=$ full surface post-emergence chemical control from the end of August. ${ }^{3} \mathrm{AB}=$ post-emergence chemical control in vine row at the end of August, full surface post-emergence chemical control from when the grape berries reached pea size (end of November). ${ }^{4} \mathrm{Chemical}$ control in vine row from end of August, work row slashed throughout the season. 'Year in which triticale was sown.

TABLE 6

Effect of different soil cultivation practices and cover crops on the $\mathrm{NO}_{3}-\mathrm{N}$ concentration in leaf petioles during full bloom of full bearing Chardonnay/99 Richter vines, established on a medium textured soil near Robertson, as measured during the third (1995/96), as well as the seventh (1999/2000) to the tenth (2002/03) season of the experiment.

Treatment

\begin{tabular}{ccccc}
\multicolumn{5}{c}{$\mathrm{NO}_{3}-\mathrm{N}(\mathrm{mg} / \mathrm{kg})$} \\
\hline $1995 / 96$ & $1999 / 2000$ & $2000 / 01$ & $2001 / 02$ & $2002 / 03$ \\
\hline 259 & 706 & 594 & 606 & 203 \\
733 & 594 & 663 & 656 & 293 \\
990 & 1431 & 1967 & 1213 & 1196 \\
883 & 744 & 881 & 719 & 447 \\
1456 & 794 & 1431 & 1338 & 960 \\
804 & 688 & 638 & 650 & 408 \\
883 & 769 & 725 & 663 & 487 \\
$771^{\mathrm{t}}$ & 856 & $863^{\mathrm{t}}$ & 656 & $440^{\mathrm{t}}$ \\
1296 & 800 & 1675 & $750^{\mathrm{t}}$ & $737^{\mathrm{t}}$ \\
266 & 714 & 856 & 650 & 310 \\
456 & 281 & 463 & 259 & 293
\end{tabular}

T1. No cover crop, $\mathrm{MC}^{1}(\mathrm{Control})$

T2. No cover crop, $\mathrm{BB}^{2}$

T3. Full surface straw mulch, BB

T4. Triticale v. Usgen 18 (triticale), BB

T5. Triticale, $\mathrm{AB}^{3}$

T6. Vicia dasycarpa Ten. (vetch), BB

T7. Vetch, AB

T8. Secale cereale L. v. Henog (rye)/Vicia faba L. v. Fiord (faba bean) mixture, BB

T9. Triticale/vetch rotated annually, BB

T10. Triticale/vetch rotated biennially, BB

T11. Festuca arundinacae L. v. Cochise (dwarf Fescue), SL ${ }^{4}$

$\operatorname{LSD}(\mathrm{p} \leq 0.05)$

293

${ }^{1} \mathrm{MC}=$ post-emergence chemical control in vine row and mechanical control in working row from the end of August. ${ }^{2} \mathrm{BB}=$ full surface post-emergence chemical control from the end of August. ${ }^{3} \mathrm{AB}=$ post-emergence chemical control in vine row at the end of August, full surface post-emergence chemical control from the end of November. ${ }^{4}$ Chemical control in vine row from the end of August, work row slashed throughout the season. ${ }^{\text {t}}$ Year in which triticale was sown. 
early in the grapevine growing season, while T2 was slightly under-supplied (Table 6). The N-deficiency experienced by the grapevines in T1 and T11 (Table 6) impacted negatively on the shoot growth and grape yield of these treatments (Table 2). The $\mathrm{NO}_{3}-\mathrm{N}$ concentration in the petioles of the grapevines in the treatments in which grazing vetch was established as cover crop and controlled chemically from the end of August (before grapevine bud break), namely T6 and T10, indicated a slight over-supply of $\mathrm{N}$ during the 1995/96 season (Table 6). This did not, however, result in excessive shoot growth in these two treatments, but in the case of T10 it impacted positively on grape yield (Table 2). These results indicate that a permanent cover crop should not be established in the work row or mechanical cultivation should not be applied in the work row of vineyards during the first four seasons after being established on medium textured soils in the Breede River Valley, as it may lead to $\mathrm{N}$-deficiencies early in the grapevine growing season.

From the seventh season (1999/2000) onwards, the permanent cover crop (T11) did not affect the $\mathrm{N}$ status of the full bearing grapevines early in the growing season negatively, with the exception of the 2002/03 season, during which the $\mathrm{NO}_{3}-\mathrm{N}$ concentration in the petioles of the grapevines indicated a serious N-deficiency (Table 6). This was attributed to the permanent cover crop being re-established during April 1998, thereby reducing the competition between the shallow-rooted young cover crop and the grapevines during the early grapevine growing season from the $1998 / 99$ to the 2001/02 seasons. This medium textured soil with a carbon content of $0.61 \%$ (Fourie, 2010) was relatively fertile according to the norms of Conradie
(1994), implying that sufficient $\mathrm{N}$ was available in the soil throughout the grapevine growing season. This might have helped to lessen competition between the growing cover in the work row and the grapevines for $\mathrm{N}$ up to the fourth season $(2001 / 02)$ after the permanent cover crop was re-established (Table 6). The N-deficiency observed in T11 during the 2002/03 season (Table 6) was attributed mainly to seasonal differences, as the $\mathrm{NO}_{3}-\mathrm{N}$ concentrations in the petioles of the grapevines of all the treatments, except T5, were lower than in the previous three seasons. As in $\mathrm{T} 11$, the $\mathrm{NO}_{3}-\mathrm{N}$ concentration in the petioles of the grapevines in $\mathrm{T} 1$ and $\mathrm{T} 2$ indicated a serious $\mathrm{N}$-deficiency in these treatments early in the 2002/03 growing season. During the $1999 / 2000$ season, the $\mathrm{NO}_{3}-\mathrm{N}$ concentration in the petioles of the grapevines in $\mathrm{T} 2$ and $\mathrm{T} 7$ indicated that the $28 \mathrm{~kg}$ of $\mathrm{N}$ applied after harvest was slightly insufficient for the early season $\mathrm{N}$ needs of the full bearing grapevines. This did not, however, have a negative impact on grapevine growth and yield (Table 3 ). The $\mathrm{NO}_{3}-\mathrm{N}$ concentration in the petioles of the grapevines in T3 was significantly higher than that of the other treatments from the 1999/2000 season onwards, with the exception of T10 during the 2000/01 season and T6 during the 2001/02 and 2002/03 season (Table 6). This was, inter alia, attributed to soil temperatures under the full surface mulch (Fourie \& Freitag, 2010) creating conditions favourable for the uptake of nutrients (McNab \& Dick, 1995). The $\mathrm{NO}_{3}-\mathrm{N}$ concentration in the petioles of the grapevines in T3 from the $1999 / 2000$ season to the 2002/03 season indicated a consistent early season over-supply of $\mathrm{N}$. This had a significantly positive effect on grape yield, whilst not promoting excessive shoot

TABLE 7

Effect of different soil cultivation practices and cover crops on the $\mathrm{N}$ concentration in the juice of young and full bearing Chardonnay/99 Richter vines, established on a medium textured soil near Robertson, as measured during the second (1994/95), fourth (1996/97), sixth (1998/99) and eleventh (2003/04) season of the experiment.

\begin{tabular}{|c|c|c|c|c|}
\hline \multirow{2}{*}{ Treatment } & \multicolumn{4}{|c|}{$\mathrm{N}(\mathrm{mg} / \mathrm{L})$} \\
\hline & $1994 / 95$ & 1996/97 & 1998/99 & $2003 / 04$ \\
\hline T1. No cover crop, $\mathrm{MC}^{1}$ (Control) & 567 & 664 & 493 & 524 \\
\hline T2. No cover crop, $\mathrm{BB}^{2}$ & 479 & 727 & 664 & 483 \\
\hline T3. Full surface straw mulch, BB & 603 & 681 & 692 & 607 \\
\hline T4. Triticale v. Usgen 18 (triticale), BB & 510 & 663 & 696 & 576 \\
\hline T5. Triticale, $\mathrm{AB}^{3}$ & 485 & 750 & 667 & 593 \\
\hline T6. Vicia dasycarpa Ten. (vetch), BB & 528 & 759 & 733 & 615 \\
\hline T7. Vetch, AB & 455 & 686 & 632 & 581 \\
\hline $\begin{array}{l}\text { T8. Secale cereale L. v. Henog (rye)/Vicia faba L. v. Fiord } \\
\text { (faba bean) mixture, BB }\end{array}$ & 485 & 708 & 664 & 581 \\
\hline T9. Triticale/vetch rotated annually, BB & 491 & 765 & 662 & $589^{t}$ \\
\hline T10. Triticale/vetch rotated biennially, BB & $521^{\mathrm{t}}$ & 790 & $705^{\mathrm{t}}$ & 660 \\
\hline T11. Festuca arundinacae L. v. Cochise (dwarf Fescue), $\mathrm{SL}^{4}$ & 283 & 639 & 668 & 528 \\
\hline $\operatorname{LSD}(p \leq 0.05)$ & 121 & 113 & 77 & 72 \\
\hline
\end{tabular}


growth. From the 2000/01 season to the 2002/03 season, the $\mathrm{NO}_{3}-\mathrm{N}$ concentration in the petioles of the grapevines of T6 was significantly higher than those of the other treatments, with the exception of T3 and T10 (2000/01 and 2002/03 seasons) (Table 6). The $\mathrm{NO}_{3}-\mathrm{N}$ concentration in the petioles of the grapevines of T10 was significantly higher than that of all the other treatments during the 2000/01 season, with the exception of T3 and T6. These results indicated that grazing vetch controlled chemically at the end of August supplied significant amounts of $\mathrm{N}$ to the grapevines during the early growing season, if sown for two consecutive years or more. Although grazing vetch created an early season over-supply of $\mathrm{N}$, it did not cause excessive vegetative growth, but resulted in above average grape yields.

\section{Juice analysis}

The trends between treatments differed from year to year as far as the sugar content, total titratable acid and $\mathrm{pH}$ were concerned. Although significant differences occurred between treatments in some years, no definite overall trend was observed (data not shown).

Juice $\mathrm{N}$ fluctuated from season to season and the trends observed between treatments also differed from year to year. The $\mathrm{N}$ concentration of the juice in the years selected to illustrate the impact that the different soil cultivation practices had on the $\mathrm{N}$ concentration in the juice over time are presented in Table 7. The $\mathrm{N}$ concentration in the juice of T11 was significantly lower than that of all the other treatments during the 1994/95 season (second season of the experiment). This abnormally low $\mathrm{N}$ concentration in the juice of T11 (W.J. Conradie, personal communication, 2010) indicated that the permanent cover crop competed strongly with the three year old grapevines for $\mathrm{N}$. The cooler soil temperatures under the full surface mulch in T3 (Fourie \& Freitag, 2010) seemed to promote the uptake of $\mathrm{N}$ by the young grapevines from the grapevine flowering stage to harvest (Table 7). Over the medium to long term (from the 1996/97 season onwards), competition between the permanent cover crop and the grapevines for $\mathrm{N}$ was not significant, as illustrated by the $\mathrm{N}$ concentration in the juice of $\mathrm{T} 11$ being normal and similar to that of most of the other treatments. During this period the $\mathrm{N}$ concentration in the juice of the treatments in which grazing vetch was sown as cover crop and full surface chemical weed control was applied from the end of August, namely T6 (from the 1996/97 season onwards), T9 (during the 1996/97 and 1998/99 seasons) and T10 (during the 1996/97 and 2003/04 seasons), always tended to be the highest. This indicated that this $\mathrm{N}$-fixing cover crop contributed positively towards the $\mathrm{N}$ status of the grapevines during the later part of the grapevine growing season.

The $\mathrm{Ca}, \mathrm{Mg}, \mathrm{K}$ and $\mathrm{P}$ concentrations in the juice fluctuated from season to season, but the trends remained fairly consistent. The years selected to illustrate the impact that the different soil cultivation practices had on the $\mathrm{Ca}, \mathrm{Mg}, \mathrm{K}$ and $\mathrm{P}$ concentrations in the juice of the grapes harvested from the young and full bearing grapevines are presented in Table 8 . The $\mathrm{Ca}$ and $\mathrm{Mg}$

\section{TABLE 8}

Effect of different soil cultivation practices and cover crops on the $\mathrm{Ca}, \mathrm{Mg}, \mathrm{K}$ and $\mathrm{P}$ concentrations in the juice of young and full bearing Chardonnay/99 Richter vines, established on a medium textured soil near Robertson, as measured during the second (1994/95) and fifth (1997/98) season of the experiment, respectively.

\begin{tabular}{|c|c|c|c|c|c|c|c|c|}
\hline \multirow[b]{2}{*}{ Treatment } & \multicolumn{4}{|c|}{$1994 / 95$} & \multicolumn{4}{|c|}{$1997 / 98$} \\
\hline & $\begin{array}{c}\mathrm{Ca} \\
(\mathrm{mg} / \mathrm{L})\end{array}$ & $\begin{array}{c}\mathrm{Mg} \\
(\mathrm{mg} / \mathrm{L})\end{array}$ & $\begin{array}{c}\mathrm{K} \\
(\mathrm{mg} / \mathrm{L})\end{array}$ & $\begin{array}{c}\mathrm{P} \\
(\mathrm{mg} / \mathrm{L})\end{array}$ & $\begin{array}{c}\mathrm{Ca} \\
(\mathrm{mg} / \mathrm{L})\end{array}$ & $\begin{array}{c}\mathrm{Mg} \\
(\mathrm{mg} / \mathrm{L})\end{array}$ & $\begin{array}{c}\mathrm{K} \\
(\mathrm{mg} / \mathrm{L})\end{array}$ & $\begin{array}{c}\mathrm{P} \\
(\mathrm{mg} / \mathrm{L})\end{array}$ \\
\hline T1. No cover crop, $\mathrm{MC}^{1}$ (Control) & 58 & 83 & 1281 & 109 & 53 & 89 & 1505 & 104 \\
\hline T2. No cover crop, $\mathrm{BB}^{2}$ & 46 & 93 & 1633 & 111 & 45 & 74 & 1330 & 81 \\
\hline T3. Full surface straw mulch, BB & 56 & 96 & 1576 & 115 & 51 & 70 & 1361 & 106 \\
\hline T4. Triticale v. Usgen 18 (triticale), BB & 47 & 88 & 1818 & 120 & 61 & 67 & 1319 & 110 \\
\hline T5. Triticale, $\mathrm{AB}^{3}$ & 58 & 100 & 1613 & 111 & 41 & 65 & 1442 & 111 \\
\hline T6. Vicia dasycarpa Ten. (vetch), BB & 53 & 92 & 1714 & 110 & 49 & 67 & 1326 & 95 \\
\hline T7. Vetch, AB & 51 & 93 & 1811 & 114 & 60 & 66 & 1424 & 101 \\
\hline $\begin{array}{l}\text { T8. Secale cereale L. v. Henog (rye)/Vicia faba L. v. Fiord } \\
\text { (faba bean) mixture, BB }\end{array}$ & 56 & 93 & 1728 & 124 & 38 & 60 & 1280 & 103 \\
\hline T9. Triticale/vetch rotated annually, BB & 58 & 97 & 1838 & 119 & $30^{t}$ & $61^{\mathrm{t}}$ & $1257^{\mathrm{t}}$ & $96^{\mathrm{t}}$ \\
\hline T10. Triticale/vetch rotated biennially, BB & $52^{\mathrm{t}}$ & $94^{\mathrm{t}}$ & $1874^{\mathrm{t}}$ & $123^{\mathrm{t}}$ & $52^{\mathrm{t}}$ & $71^{\mathrm{t}}$ & $1359^{\mathrm{t}}$ & $98^{\mathrm{t}}$ \\
\hline $\begin{array}{l}\text { T11. Festuca arundinacae L. v. Cochise (dwarf Fescue), } \\
\text { SL }^{4}\end{array}$ & 78 & 126 & 1915 & 126 & 74 & 104 & 1749 & 127 \\
\hline $\operatorname{LSD}(p \leq 0.05)$ & 11 & 10 & 177 & NS & 21 & 9 & 168 & 23 \\
\hline
\end{tabular}

${ }^{1} \mathrm{MC}=$ post-emergence chemical control in vine row and mechanical control in working row from the end of August. ${ }^{2} \mathrm{BB}=$ full surface post-emergence chemical control from the end of August. ${ }^{3} \mathrm{AB}=$ post-emergence chemical control in vine row at the end of August, full surface post-emergence chemical control from when the grape berries reached pea size (end of November). ${ }^{4} \mathrm{Chemical}$ control in vine row from end of August, work row slashed throughout the season. ${ }^{\text {t}}$ Year in which triticale was sown. 
concentrations in the juice of the young grapevines in T11 were significantly higher than those of the other treatments during the 1993/94 season. The K concentration in the juice of the young grapevines in $\mathrm{T} 11$ was the highest and significantly higher than those of T1, T2, T3, T5, T6 and T8. Although the P concentration in the juice of the young grapevines did not differ significantly between treatments, it was also the highest in T11. Similar results were reported by Soyer et al. (1984) and Sicher et al. (1995) who found that the $\mathrm{P}$ and $\mathrm{K}$ concentrations in the leaves of grapevines grown under a permanent grass cover crop were significantly higher than that of grapevines grown under full surface chemical weed control or mechanical soil cultivation. The harvest in T11 being the lowest during this season (Table 2) might have contributed towards the observed trends (Table 8).

The $\mathrm{Mg}$ and $\mathrm{K}$ concentrations in the juice of the full bearing grapevines in T11 were significantly higher than that of the other treatments during the 1997/98 season (Table 8). The $\mathrm{Ca}$ concentration in the juice of the full bearing grapevines in T11 remained the highest and was significantly higher than that of the other treatments, with the exception of T1 and T7. The P concentration in the juice of the full bearing grapevines in T11 also remained highest and was significantly higher than those of the other treatments, with the exception of T1, T3, T4 and T5.

\section{Experimental wines}

No significant differences in wine quality were observed between treatments. (data not shown).

\section{CONCLUSIONS}

Full surface post-emergence chemical control should be applied from the end of August to just before harvest in young vineyards established on medium textured soils in the Breede River Valley wine grape region. Cover crops should be sown annually and controlled chemically before bud break, as it will enhance the development of the permanent structure of trellised grapevines. A permanent cover crop should not be established, and mechanical cultivation should not be applied, in the work rows of vineyards during the first five seasons after being established on medium textured soils in the Breede River Valley, as it may lead to early season $\mathrm{N}$-deficiencies and affect shoot growth and yield negatively.

It is beneficial to the performance of full bearing grapevines to chemically control a cover crop before bud break, rather than allowing it to complete its life cycle, especially where grazing vetch is used as cover crop. Although grazing vetch controlled chemically at the end of August may create an early season over-supply of $\mathrm{N}$ if sown for two consecutive years or more, it will not necessarily cause excessive shoot growth, but may result in above average grape yields over the long term. This $\mathrm{N}$-fixing cover crop also contributed positively to the $\mathrm{N}$ status of the grapevines during the later part of the grapevine growing season. A full surface straw mulch packed out annually promotes early season uptake of $\mathrm{N}$ and has a significant positive impact on grape yield over the long term. It seems that the competition for nutrients between the full bearing grapevines and the permanent cover crop was rendered negligible by the relatively fertile medium textured soil used in the study.

Although the different soil management practices affected grape yield significantly over the 12-year period, they had no significant effect on wine quality.

\section{LITERATURE CITED}

Anonymous, 1984. Versuchergebnisse der staatlichen Weinbauinstitut. Rebe und Wein 4, 156-159. In: Sicher, L., Dorigoni, A. \& Stringari, G., 1995. Soil management effects on nutritional status and grapevine performance. Acta Hort. 383, 73-82.

Anonymous, 1997. Onkruide se weerstand teen middels wek kommer. Landbouweekblad 7 November, 95.

Booysen, J.H., Steenkamp, J. \& Archer, E., 1992. Names of vertical trellising systems (with abbreviations). (In Afrikaans). Wynboer September, 15.

Buckerfield, J.C. \& Webster, K.A., 1996. Earthworms, mulching, soil moisture and grape yields. Wine Indust. J. 11, 47-53.

Conradie, W.J., 1994. Vineyard fertilization. Proceedings of a workshop on vineyard fertilization, Nietvoorbij, 30 September, ARC - Fruit, Vine and Wine Research Institute, Private Bag X5026, Stellenbosch, 7599 R.S.A.

Conradie, W.J., 2001. Timing of nitrogen fertilization and the effect of poultry manure on the performance of grapevines on sandy soil. II. Leaf analysis, juice analysis and wine quality. S. Afr. J. Enol. Vitic. 22, 60-68.

Cousens, R. \& Mortimer, M., 1995 ( $1^{\text {st }}$ ed). Dynamics of weed populations. Cambridge University Press, Cambridge.

Dupuch, V., 1997. Entretien des sols viticoles et consequences oenologiques. Progrès Agricole et Viticole 114, 152-156. In: Horticultural Abstracts 68, 396.

Fourie, J.C., 2005. Cover crop management in the vineyards of the Lower Orange River region, South Africa: 1. Performance of grass and broadleaf species. S. Afr. J. Enol. Vitic. 26, 140-146.

Fourie, J.C., 2010. Soil management in the Breede River Valley wine grape region, South Africa. 1. Cover crop performance and weed control. S. Afr. J. Enol. Vitic. 31, 14-21.

Fourie, J.C. \& Freitag, K., 2010. Soil management in the Breede River Valley Wine Grape Region, South Africa. 2. Soil temperature. S. Afr. J. Enol. Vitic., 31, 165-168.

Fourie, J.C., Louw, P.J.E. \& Agenbag, G.A., 2001. Effect of seeding date on the performance of grasses and broadleaf species evaluated for cover crop management in two wine grape regions of South Africa. S. Afr. J. Plant Soil $18,118-127$.

Fourie, J.C., Louw, P.J.E. \& Agenbag, G.A., 2005. Cover crop management in a Sauvignon blanc/Ramsey vineyard in the semi-arid Olifants River Valley, South Africa. 1. Effect of management practices on selected grass and broadleaf species. S. Afr. J. Enol. Vitic. 26, 131-139.

Fourie, J.C., Louw, P.J.E. \& Agenbag, G.A., 2006a. Cover crop management in a Chardonnay/99 Richter vineyard in the Coastal wine grape region, South Africa. 1. Effect of two management practices on selected grasses and broadleaf species. S. Afr. J. Enol. Vitic. 27, 167-177.

Fourie, J.C., Louw, P.J.E. \& Agenbag, G.A., 2006b. Cover crop management in a Chardonnay/99 Richter vineyard in the Coastal wine grape region, South Africa. 2. Effect of different cover crops and cover crop management practices on grapevine performance. S. Afr. J. Enol. Vitic. 27, 178-186.

Fourie, J.C., Louw, P.J.E. \& Agenbag, G.A., 2007. Cover crop management in a Sauvignon blanc/Ramsey vineyard in the semi-arid Olifants River Valley, South Africa. 2. Effect of different cover crops and cover crop management practices on grapevine performance. S. Afr. J. Enol. Vitic. 28, 81-91.

Fourie, J.C., Louw, P.J.E. \& Calitz, F.J., 2006c. Effect of seeding date on the performance of grasses and broadleaf species evaluated for cover crop management in the Breede River Valley wine grape region of South Africa. S. Afr. J. Enol. Vitic. 27, 8-14. 
Henkes, R., 1997. Handling herbicide resistance. The furrow 102, 8-11.

Ingels, C.A., Scow, K.M., Whisson, D.A. \& Drenovski, R.E., 2005. Effects of cover crops on grapevines, yield, juice composition, soil microbial ecology, and gopher activity. Am. J. Enol. Vitic. 56, 19-29.

Khan, M.J., Monke, E.J. \& Foster, G.R., 1986. Mulch cover and canopy effect on soil loss. Pap. ASAE no 86-253. Dept of Agric. Eng. Purdue Univ. West Lafayette, In. 47907, USA.

Lombard, P., Price, S., Wilson, W. \& Watson, B., 1988. Grass cover crops in vineyards. Proceedings Second International Cool Climate Viticulture and Oenology Symposium, Auckland, New Zealand, January, 152-155.

Louw, P.J.E. \& Bennie, A.T.P., 1992. Water runoff and soil erosion in vineyard soils. Austr. Grapegrower \& Winemaker Annual Technical Issue, 100-113.

Maigre, D., 1997. Influence de l'enherbement et de la fumure, azotée sur la qualité des vins de Chasselas. Progrès Agricole et Viticole 114, 255-258. In: Hort. Abstr. 68, 769.

McNab, S. \& Dick, R., 1995. Soil temperature and moisture levels can affect fertiliser breakdown in vineyards. Austr. Grapegrow. Winemaker Annual Technical Issue, 141-142.

Myburgh, P.A., 1998. Water consumption of South African vineyards: A modeling approach based on the quantified combined effects of selected viticultural, soil and meteorological parameters. Ph D dissertation, Stellenbosch University, Private Bag X1, 7602 Matieland (Stellenbosch), South Africa.

Pinamonti, F., Stefanini, M. \& Dalpiaz, A., 1996. Soil management effects on nutritional status and grapevine performance. Vitic. Enol. Sci. 51, 76-82.

Pool, R.M., Dunst, R.M. \& Lakso, A.N., 1990. Comparison of sod, mulch, cultivation, and herbicide floor management practices for grape production in non-irrigated vineyards. J. Amer. Soc. Hort. Sci. 115, 872-877.

Reeves, D.W., 1997. The role of soil organic matter in maintaining soil quality in continuous cropping systems. Soil \& Tillage Res. 43, 131-167.

Roth, C.H., Meyer, B., Frede, G. \& Derpsch, R., 1988. Effect of mulch rates and tillage systems on infiltrabillity and other soil physical properties of an Oxisol in Parana, Brazil. Soil \& Tillage Res. 11, 81-91.
SAS, 1990. SAS/STAT users guide, version 8, first edition, volume 2. SAS Institute Inc., Campus drive, Cary NC 27513.

Shapiro, S.S. \& Wilk, M.B., 1965. An analyses of variance test for normality (complete samples). Biometrika 52, 591-611.

Shennan, C., 1992. Cover crops, nitrogen cycling, and soil properties in semiirrigated vegetable production systems. HortScience 27, 749-754.

Sicher, L., Dorigoni, A. \& Stringari, G., 1995. Soil management effects on nutritional status and grapevine performance. Acta Hort. 383, 73-82.

Soyer, P., Delas, J., Molot, C., Andral, P. \& Casteran, P., 1984. Techniques d'entretien du sol en vignoble bordelaise. Progr. Agric. Vitic. 101, 315-320.

Tan, S. \& Crabtree, G.D., 1990. Competition between perennial ryegrass sod and 'Chardonnay' wine grapes for mineral nutrients. HortScience 25, 533-535.

The Non-Affiliated Soil Analysis Work Committee, 1990. Handbook of standard soil testing methods for advisory purposes. Soil Sci. Soc. South Africa, P.O. Box 30030, Sunnyside, Pretoria.

Tromp, A. \& Conradie, W.J., 1979. An effective scoring system for sensory evaluation of experimental wines. Am. J. Enol. Vitic. 30, 278-283.

Van Huyssteen, L., 1990. The effect of soil management and fertilization on grape composition and wine quality with special reference to South African conditions. Proc. $7^{\text {th }}$ Australian Wine Industry Conference, 13-17 August, 1989, Adelaide, South Australia. pp. 16-25.

Van Huyssteen, L., Van Zyl, J.L. \& Koen, A.P., 1984. The effect of cover crop management on soil conditions and weed control in a Colombar Vineyard in Oudtshoorn. S. Afr. J. Enol. Vitic. 5, 7-17.

Van Huyssteen, L. \& Weber, H.W., 1980. The effect of selected minimum and conventional tillage practices in vineyard cultivation on vine performance. S. Afr. J. Enol. Vitic. 1, 77-83.

Westra, P., Wilson, R.G., Miller, S.D., Stahlman, P.W., Wicks, G.W., Chapman, P.L., Withrow, J., Legg, D., Alford, C. \& Gaines, T.A., 2008. Weed population dynamics after six years under glyphosate- and conventional herbicide-based weed control strategies. Crop Sci. 48, 1170-1177. 